\title{
Germany edges towards stem-cell accord
}

Quirin Schiermeier, Munich

Political agreement over the use of human embryos in research remains elusive in Germany. But, judging by a ground-breaking three-day symposium held in Berlin last week, the gap between the extreme positions is narrowing.

Organized by Germany's federal health minister, Andrea Fischer, the meeting addressed the scientific, medical, ethical and legal aspects of reproductive medicine. In particular, the aim was to lay the groundwork for a possible revision of Germany's embryo research laws - currently the strictest in Europe.

The meeting was intended to complement the work of an all-party parliamentary commission, set up earlier this year to identify the areas where scientific advances have exposed a lack of legal rules (see Nature 404, $692 ; 2000)$. More than 600 geneticists, physicians, ethicists, theologians and women's and disabled persons' rights activists took part.

At a concluding press conference, Fischer called the symposium a great success. "It was extremely important for us all to meet our opponents and listen to them," she said. "Now I can see much clearer the pros and cons of the most recent biomedical opportunities."

Fischer, a member of the Green party, had said earlier that she was keen to start a broad discussion on both medical opportunities and the necessary ethical boundaries of biomedical research. Especially in the light of a possible revision of Germany's ten-year-old embryo protection law, which would turn it into a more comprehensive law on reproductive medicine.

The current law outlaws research on in vitro stem cells from human embryos and pre-implantation diagnostics. It has come under fire from many scientists, physicians and legal experts as being outdated, given the speed of advances in the life sciences and the less restrictive legislation in force elsewhere in Europe and the United States.

Presentations to the symposium suggested that although controversy remains over issues such as genetic 'selection' and eugenics, extreme positions are on the wane. But sharp divisions remain over whether advances in biomedicine and genetics are a benefit or a threat to society.

Fischer said that she personally would prefer to maintain tough restrictions on the applications of such techniques, on the basis that pre-implantation diagnostics and genetic screening could lead to a gradual 'devaluation' of sick people and discrimination against the disabled.

Dietmar Mieth, head of the Centre for Ethics in Science at the University of Tübingen and a member of the federal health ministry's ethics commission, says that although

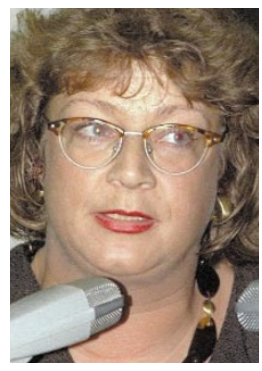

Fischer: encouraging debate over stem-cell research. scientific freedom is guaranteed in Germany's post-war constitution, this freedom cannot be interpreted as absolute, particularly in the ethically sensitive area of biomedicine.

This view is shared by Jens Reich, a bioinformaticist at the Max Delbrück Centre for Molecular Medicine in Berlin and the Greens' 1994 candidate for federal president.

Mieth argues that the embryo protection law should be retained. But he would like it supplemented by additional legislation on genetic diagnostics, which would include detailed regulations on pre-implantation diagnostics, and take into account the results and medical implications of the Human Genome Project.
Experts on both sides agreed that if Germany maintains its comparatively restrictive attitude to areas of biomedicine relating to human embryos, the result will be a form of medical and scientific 'tourism' as researchers seek less onerous conditions in neighbouring countries.

But Mieth rejects the argument that excessive restrictions could cut Germany off from frontline biomedical research in areas such as stem-cell research. "Concern and caution are not German quirks," he says. "Stem-cell research is equally controversial in France and in the UK."

The symposium also raised questions about the value of academic and practical ethics in the decision-making process. Kurt Bayertz, a philosopher at the University of Münster, argued that consensus can only be achieved on a political level. Ethics have no affinity to consensus, he said, in the context of problems such as the moral status of the human embryo.

\section{Survey nets volcanic prize}

\section{Peter Pockley, Sydney}

The largest volcanic chimney ever to be recovered from the sea floor is being brought ashore by an international team working for the Commonwealth Scientific and Industrial Research Organisation. Caught by the marine research vessel

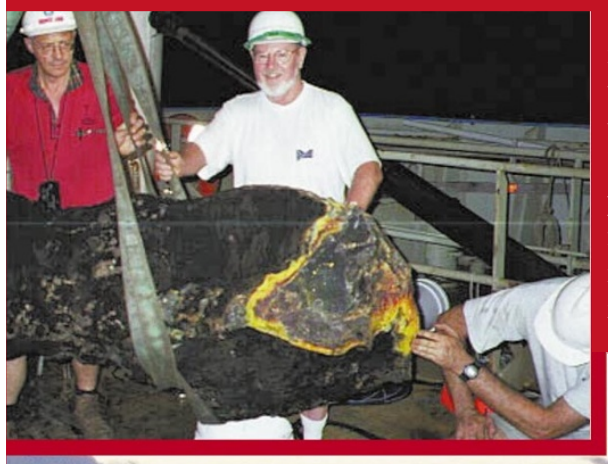

Franklin during an expedition focusing on mineral formation in the Western Pacific Ocean, the chimney (inset) is $2.7 \mathrm{~m}$ high, 70-80 $\mathrm{cm}$ across and weighs one tonne. It was snagged by a dredging net during a routine survey of the Eastern Manus Basin in the Bismarck Sea.

The research team also witnessed remarkable island-building activity as the marine volcano Kavachi erupted for the first time in nine years (below). Kavachi, near the Solomon Islands, produced eruptions 800 metres high every five minutes, ejecting ash and incandescent blocks of lava up to 70 metres above sea level. 